\title{
VOLUNTEER PARTICIPATION IN CITIZEN SCIENCE PROJECTS
}

\author{
Participación de voluntarios en proyectos \\ de ciencia ciudadana
}

\section{Núria Ferran-Ferrer}

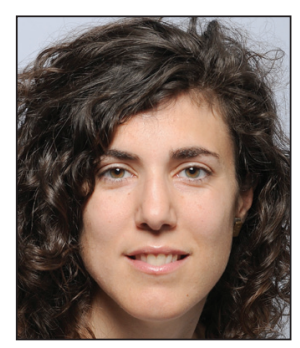

Núria Ferran-Ferrer is a lecturer at the Department of Information and Communication Sciences, Universitat Oberta de Catalunya (UOC) since 2005. She had her European doctoral degree in 2010 at the Universitat Barcelona, with a research stage at Sheffield University (2009). In her dissertation she studied the transfer of knowledge, abilities and attitudes of information-related behaviours from professional and social to private life. She has been assistant professor of Information Management and User Studies from 2004 to 2008 in the Information Management and Journalism Bachelors at the Universitat Autònoma de Barcelona, and she is at present teaching at UOC research methodologies for user centred design processes, user experience and human-computer interaction. She is currently involved in a national funded research project on open science where she is supervising a PhD dissertation about the attitudes and knowledge of academics towards the reuse of academic works. Her research interests span from open content and participation on science to user experiences with digital media and mobile devices.

http://orcid.org/0000-0002-9037-8837

Universitat Oberta de Catalunya (UOC) Rambla del Poblenou, 156. 08018 Barcelona, Spain nferranf@uoc.edu

\begin{abstract}
The purpose of this research is to assess the current state of citizen science projects and reveal the role of volunteers in the research process. This is achieved by performing a literature review and content analysis of three international and one state-owned citizen science platforms (Wikipedia, SciStarter, CitSci and Precipita) that contain more than 800 research projects. Projects have been analyzed according to four categories: the academic disciplines, the way the project is designed, the phases of the research in which volunteers participate, and the tasks they perform. The results show that projects in the arts, humanities, and social sciences disciplines are almost non-existent. In addition, in the field of natural and physical sciences, projects are fostered with a top-down approach and volunteers participate primarily in the data collection phase in order to obtain a large volume of data, thereby receiving more financing from the European Union.
\end{abstract}

\section{Keywords}

Citizen science; Crowd science; Big data; Open data; Social sciences; Arts; Humanities; AHSS.

\section{Resumen}

Estado de la cuestión de los proyectos de ciencia ciudadana, profundizando en el papel de los voluntarios en el proceso de investigación. Se realiza una revisión bibliográfica y se analiza el contenido de tres plataformas de la ciencia ciudadana de dimensión internacional y una de propiedad estatal (Wikipedia, SciStarter, CitSci y Precipita) que contienen más de 800 proyectos de investigación. Los proyectos han sido analizados según cuatro variables: las disciplinas académicas, su diseño, la fase de la investigación en que los voluntarios participan y las tareas que realizan. Los resultados demuestran que este tipo de proyectos en ciencias sociales, arte y humanidades son casi inexistentes. Pero en el ámbito de las ciencias naturales y físicas, estos proyectos se diseñan desde arriba hacia abajo, los voluntarios participan en la fase de recogida de datos para proporcionar un gran volumen de datos y reciben más financiación de la Unión Europea.

\section{Palabras clave}

Ciencia ciudadana; Datos masivos; Datos en abierto; Ciencias sociales; Arte; Humanidades; AHSS.

Ferran-Ferrer, Núria (2015). "Volunteer participation in citizen science projects". El profesional de la información, v. 24, n. 6, pp. 827-837. 


\section{Introduction}

The number of devices that capture, produce, and transmit data has risen exponentially in the last 15 years. Along with this explosion of data are new ways of resolving problems and posing questions, which are already changing how value is added to the economy, how politics and society are organised and how science is carried out (Subirós; De-Vicente, 2014).

It is in this new data environment the terms crowd science or citizen science ${ }^{1}$ are used to refer to citizens involved in scientific research projects. These projects can be worked on in a massive scale -participating many citizens- and generate large volumes of high-quality data with scientific results on par with any other research project carried out by professional researchers (Hunter et al., 2012; Wiggins; Crowston, 2012).

Using citizen scientists, research is not limited by location and data can be analyzed anywhere a computer can be found. It is no longer a playing field limited to universities, academic institutions, laboratories, or the research and innovation departments of companies (Franzoni; Sauermann, 2014). Citizens can now participate in scientific projects thanks to mobile technologies and the popularization of web 2.0

Citizen science participation is requested through open calls. The tasks generally reserved for citizens are the collection of data for natural and physical sciences projects, whether the data are on the environment (weather observation, research on the quality of water, sighting of birds or butterflies, etc.), astronomy, or biochemistry (Wiggins; Crowston, 2012; Dawson, 2012). In projects in the fields of natural and physical sciences, the objectives usually pursue "the improvement of knowledge, the conservation of the different components of the natural environment and ensure that the large volume of general data (big data) follow the protocols which guarantee scientific validity and applicability" (Museu de Ciències Naturals; Institució Catalana d'Història Natural, 2010). Citizen participation makes it possible to obtain massive quantities of data at a low cost by means of validity systems and verification tools, and the fact that volunteers are not required to have any specific academic training, the training they do receive is limited, and their contributions anonymous, pose no hindrance to scientific research methods (Hunter et al., 2012).

\section{Crowd science or citizen science are used to refer to citizens involved in scientific research projects}

Citizen science projects do not normally include research ones related to daily life nor closely linked to arts, humanities, and the social sciences (AHSS) (Purdam, 2014). It is also uncommon for volunteers to generate bottom-up initiatives for the design, analysis, and publication of research results.

The following section includes a thorough review of the literature related to citizen science projects and a discussion about four dissemination platforms; emphasis is placed on user tasks, thematic areas, project structure, and the importance attached to the quantity of data collected. The research and innovation funding programs are also analyzed within the framework of the European Union.

\section{Characteristics of citizen science projects}

In the nineteenth century scientific research was not limited to scientists. Instead, ordinary citizens who loved science participated in it, especially those who were intrigued by the biodiversity of our planet. But it was not until recent years, that there has been an explosion of research projects involving average citizens.

Compared with nineteenth century naturalists, today's scientific citizens enjoy the benefits of access to information, online communication technologies, and crowdsourcing capabilities (Busch, 2013)2.

The paper White paper on citizen science in Europe (Socientize Consortium, 2014) includes a broad definition of citizen science and encompasses any and all types of active contribution to science through intellectual efforts, knowledge, tools, and resources. The belief is that an exchange has to take place: participants add value to the projects and, in exchange, they receive learning,

http://boinc.berkeley.edu 
skills and knowledge, among other aspects (Zhao; Zhu, 2014).

Perelló (2014) states that the success of these projects began in 1999 with the project Seti@home, which used the personal computers of volunteers to detect signs of artificial intelligence beyond Earth; subsequently other projects were developed. For example, the platform Boinc which began in 2002 has had hundreds of thousands of volunteers and more than twenty projects -its success can be seen in the numerous articles that have been published in prestigious scientific journals as a result of citizen participation.

The participation rate and data collection figures of citizen science projects tend to be large and successful. For example, Zooniverse is a project that receives small contributions from over a million volunteers.

Citizen scientists have examined and classified the shape of the images taken by a robotic telescope, providing evidence of patterns that is much more accurate than any computer program could produce. As a result, $300 \mathrm{mi}-$ Ilion pieces of data have been analyzed, 150 million galaxies registered, and scientific articles with the results have been published in more than fifty peer-reviewed publications. The work would not have been finished nearly as early, nor the analysis of such a large quantity of data completed so quickly, with a smaller team of professional scientists.

\section{There are so many people collecting data that the likelihood that the data are inaccurate is virtually non-existent}

The participants in the projects do not necessarily have scientific training, nor is it required. Despite this de-professionalization and the creation of a large quantity of data, the projects follow the scientific method. To ensure quality, the data collection protocols have to be established prior to the study and involvement of citizen scientists. Once the data have been collected, in the analysis phase, it is worthwhile repeating the observations or established quality control methods (Antelio et al., 2012). There are so many people collecting data that the likelihood that the data are inaccurate is virtually non-existent.

Citizen participation projects are within the framework of a global and far-reaching movement that promotes, among other things, free access to open-source contents and tools. This movement, called Commons, includes in its ideals free access to natural resources, free spaces, heritage and knowledge, as they are understood to be part of the "common good" and, hence, they must be preserved and accessible in a universal manner (Tomales Bay Institute, 2006).
Citizen participation in science shares two essential characteristics with the Commons movement: open data and open participation (Franzoni; Sauermann, 2014). Thus, the data and algorithms to resolve problems that the projects produce or the resulting publications have to be accessible to all.

Research data being made public came to be a fairly standard practice with studies on the genome at the beginning of the ' 80 s, and in 1996, at the conference in Bermuda (Bermuda, 1996), all of the scientists in this field agreed that this should be the norm if funding was being received from public sources. Taking this from a political wish to reality was the principal contribution of the Berlin declaration (2003) on open access to knowledge in all academic fields. It established that institutions should encourage and even require scientists to provide open access to the results of their own research (Nielsen, 2011).

Among the many definitions of the concept of citizen science, open access to research results is evidently included, but it goes one step further in that it also opens up access to field data (Franzoni; Sauermann, 2014). The current program in force for the financing of European research and innovation, Horizon 2020, coincides with this vision, and all the projects that receive funding are obliged to give access to their publications and make their research data accessible (European Commission, 2013).

Regarding opening up projects to participation, citizen science projects tend to be collaborative and virtual, using 2.0 initiatives like those of Wikipedia or OpenStreetMap, which use the wisdom of the masses (wisdom of crowds). http://www.wikipedia.org http://www.openstreetmap.org 


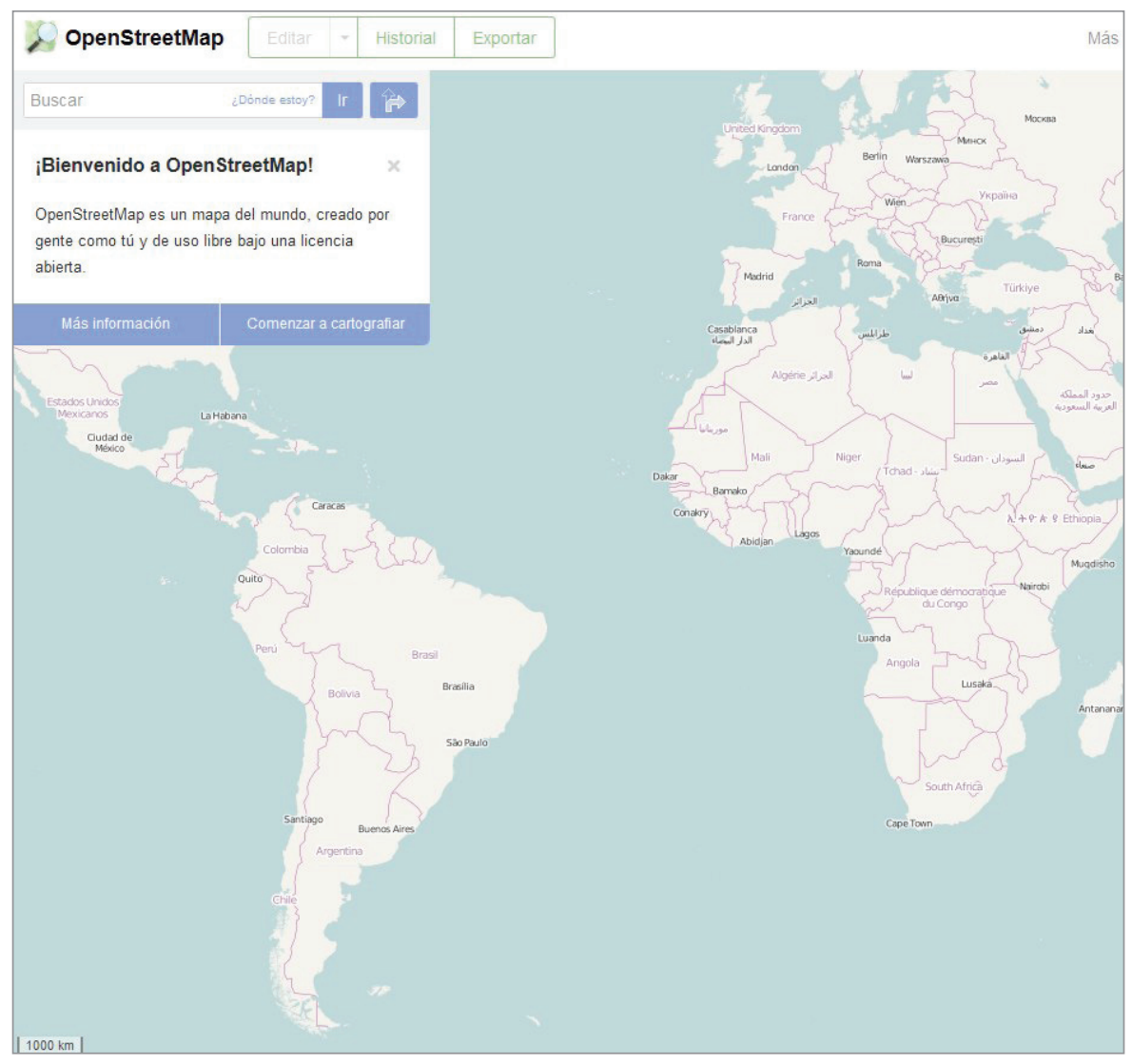

http://www.openstreetmap.org

Thus, the opportunity provided by projects carried out this way is that they can reach everyone, everywhere, since practically everyone is guaranteed to have Internet access and a smartphone. These aforementioned devices, which incorporate applications and tools with cameras, registers, and geolocators, among others, mean that anyone can have sensors, termed "wearables", on them, which can send data that can be collected anywhere in the world (Wechsler, 2014).

Science lovers, like any individual from any point on the planet, use connected devices, which produce data, which in many cases are transmitted via the Internet. The sources of the data can be meteorological stations, pollution sensors, and even mobile telephones, as they have light sensors incorporated - those of proximity, sound, GPS positioning and barometer, among many others. McLuhan's paradigm on technology, understood as an extension of the human body, which allows it and its cognitive functions to be amplified (1966), is executed to its fullest extent in the field of citizen science.

With the data generated and observations made by the participants, it is a demonstrable fact that the principal objectives of these projects is the capturing of big data at a reduced cost, so that professional scientists can investigate and solve research questions (Trumbull et al., 2000; Clark; Illman, 2001). Science lovers are contributors to the project; therefore, the implication of the volunteers in the methodology and its design is contributory and not collaborative or co-creative (Bonney et al., 2009).

\section{Project dissemination platforms for citizen participation in science}

As has been previously stated, for a research project to be considered a citizen science project, it is essential that it be open to all. Based on this premise, various platforms, which help to disseminate active projects, were analysed. The most common dissemination platforms, providing access to more than 800 projects, are Wikipedia, SciStarter, CitSci; this study also wanted to size up what was happing in Spain, where there is only one platform for citizen science projects, Precipita. The analysis was conducted from December 2014 to January 2015.

The following is a description and analysis of the content of these platforms in relation to four categories of study:

\section{a) Discipline}

Derived from the work of Purdam (2014) to determine the thematic field and the proportion of physical and natural science projects in relation to arts, humanities and social sciences.

\section{b) Task}

Refers to the activities performed by volunteers, to see what they do, the level of difficulty of the activity and the stages of the research process in which they are involved. It is a category resulting from the research of Wiggins \& Crowston (2012).

\section{c) Volume of data}

Whether this is to prioritize the qualitative or quantitative aspect (Subirós; De-Vicente, 2014) or, to the contrary, to pursue the more qualitative and singular. This category has been created on a well-founded basis from the analysis of transcriptions and interviews carried out on different initiatives in citizen science in the sphere of social sciences and humanities.

\section{d) Design of research projects}

How the research initiative has been planned; if it has been designed exclusively by researchers (top-down) and consequently with projects of the contributory type, or of a social origin with citizen participation (bottom-up) with collaborative or co-creative methodology (Gómez-Ferri, 2014).

For each platform the thematic classification of the search system for projects was analyzed in order to ascertain the academic discipline for each project. Then each project description was analyzed in order to gather the data for the rest of the study variables. The following presents the analysis 
of the more than 800 citizen science projects through these four platforms:

\section{Wikipedia: List of citizen science pro- jects}

http://en.wikipedia.org/wiki/List_of_citizen_ science_projects

It is an entry point in Wikipedia with a list of science projects with citizen participation that are active, and a list of closed projects so that "ordinary people can contribute significantly to scientific research".

a) Discipline: the majority of the projects are of the natural and physical sciences type ( 81 projects). The most predominant disciplines are: biology (11 projects), ornithology (12) and astronomy (5). Only one of the 81 projects is from social sciences and it is linguistics.

b) Task: the volunteers' main activity is focused on the data collection phase. Main activities are related to the collection of data through transcriptions and observations.

c) Volume of data: the projects attach importance to the quality of data collected. A project goes from "active" to "closed" on the platform when its data collection objectives are reached. This is what we call big data. By way of example, there is the project Old weather, which at the beginning of 2013 already had $12 \%$ of the logs completed $(19,604$ pages); when it reaches $100 \%$ it will moved to the completed projects. A large number of data is required to reach the goal.

d) Design of research projects: the projects are clearly topdown. The researchers or their entities propose and make known the calls for participation.

\section{SciStarter}

http://scistarter.com

This North American platform indexes and enables citizens to sign up to participate in more than 600 scientific projects. It is accompanied by a very popular blog, Project Finder, which annually highlights the ten best citizen science projects from the metrics of your browser.

http://scistarter.com / blog/2014/01/top-13-citizenscience-projects-2013/\#sthash. Iw1PI2PN.dpbs

a) Discipline: the majority of the projects are in the area of the natural and physical scien-

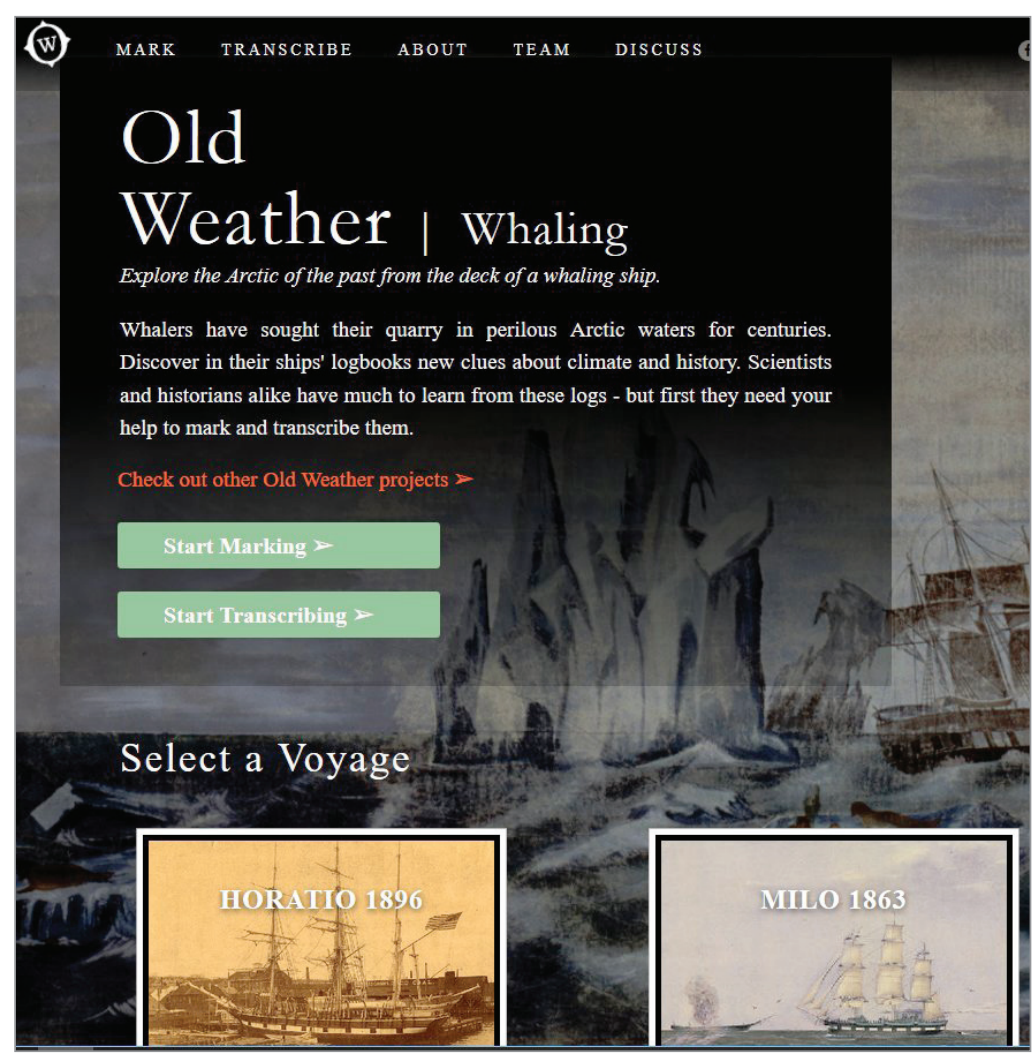

http://whaling.oldweather.org

ces, although this is difficult to count because there are both "animals" and "birds" categories. Only the categories "archaeology" and "education", of a total of 23 categories, could be considered to be from the field of arts and humanities. In the case of educational projects there are

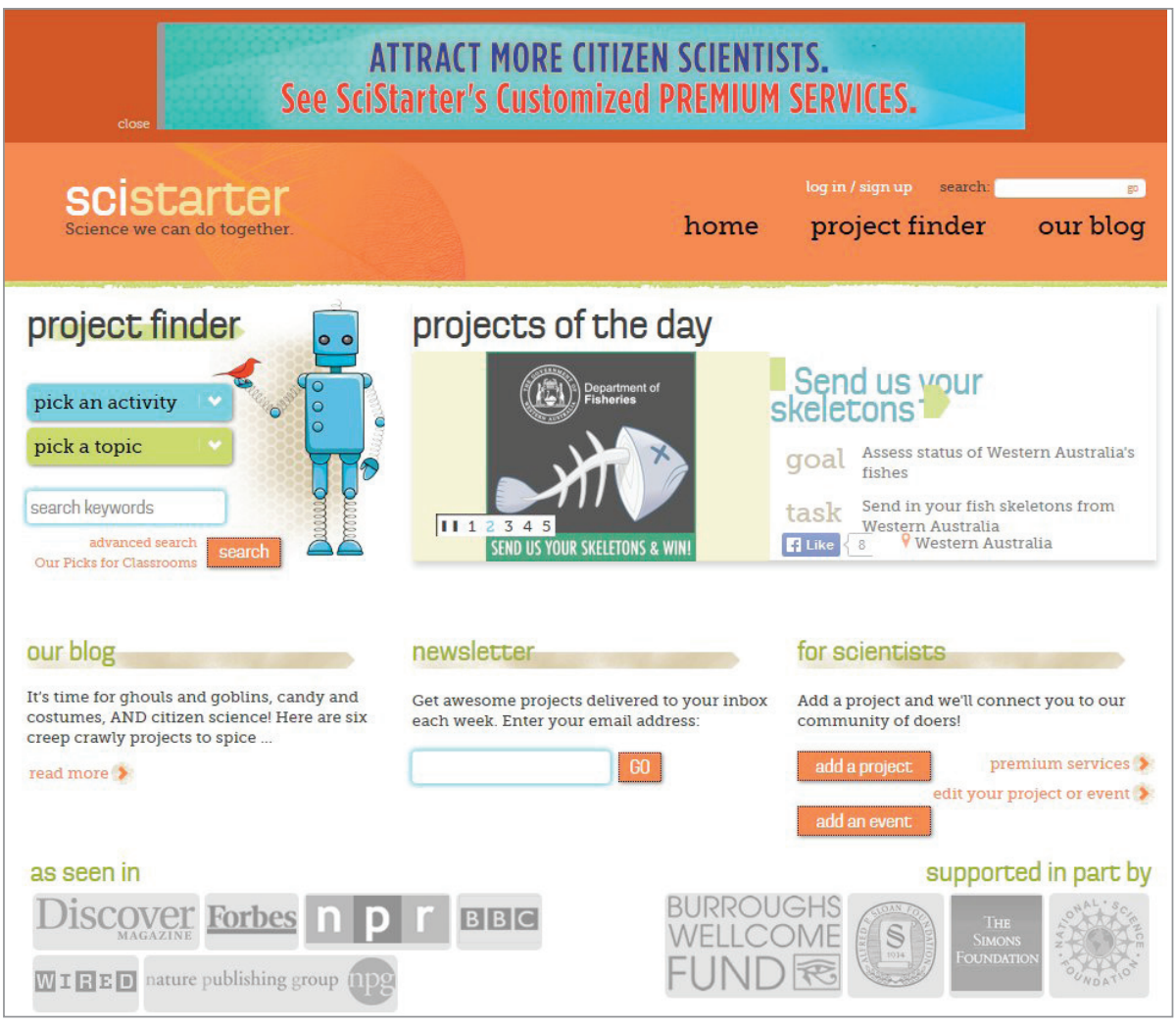

http://scistarter.com 


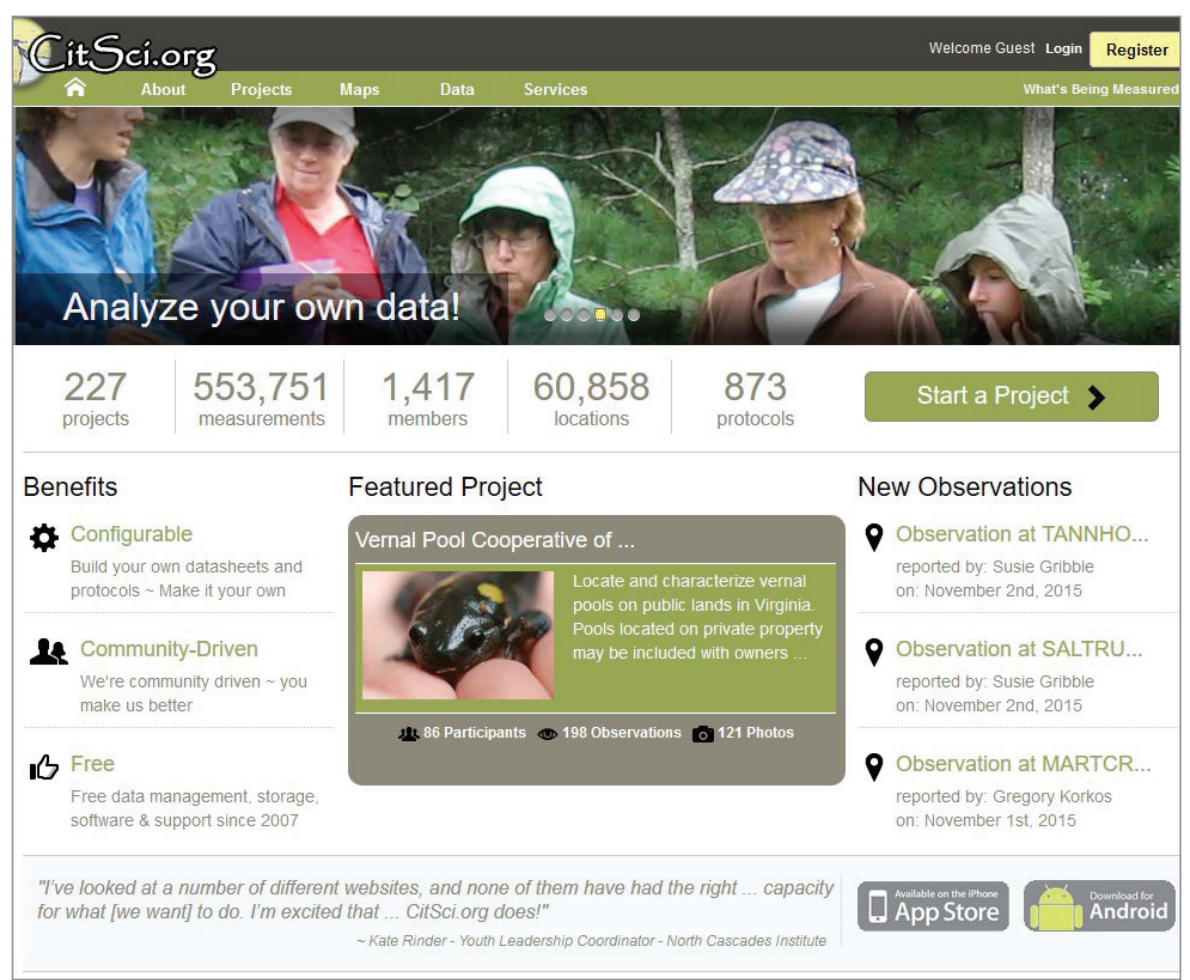

http://citsci.org

no research aims other than training participants through scientific activity. Among the objectives of the platform, the expression "get their hands dirty with science" stands out, and so, of the hundreds of projects that can be found on this platform, the majority are experiments outdoors or in laboratories.

b) Task: the projects that the platform gathers focus on tasks relating to the collection of data. Nevertheless, the high number of projects focused on training stands out, and it is a distinctive feature of the platform's mission which is to get primary and secondary schools to participate in science in a fun way.

c) Volume of data: a great deal of importance is attached to quantity. The slogan of the platform is "to liaise millions of scientific citizens with millions of projects". The aim of the platform is to be a link between science and society, so that volunteers are not only involved in research processes but also in the search to promote the role of science and technology in society.

d) Design of the research project: clearly a top-down approach. The platform possesses a specific section to register projects, which carries the label "For scientists", a title that clearly lets users know that only researchers can propose projects.

\section{CitSci}

http://citsci.org

This platform empowers citizens in their scientific interests. It offers support, tools, and resources for scientific processes, which are intended to be done with citizen participation. The platform was initially created with money from the National Science Foundation (NSF) and gives support/backup to monitoring activities and observations, but it now con- sists of volunteers connected to research groups and deals with a variety of projects. The platform is presented as "your research partner" because it is offered as a back-up to the research process.

a) Discipline: the majority of projects are of the natural and physical sciences type.

b) Task: volunteers participate in the collection of data. Emphasis is placed on the fact that their tasks should respond to motivations related to learning and fun.

c) Volume of data: importance is placed on quantity. By way of example, the platform emphasizes that to date (November 2014) it has managed more than 100 projects and has contributed to almost 30,000 observations of species.

d) Design of the research project: projects are top-down, despite the fact that the vocation of the platform is bottom-up, as the objective sought is to give support to research processes.

\section{Precipita \\ http://www.precipita.es/descubre.htm/}

This platform launched in 2014 and was created and promoted by the Spanish Foundation for Science and Technology (Fecyt) and currently has about fifteen projects through which citizens can participate in science. The creation of the Fecyt in Spain coincided with the expansion of a new model to support the relationship between science and the public. Additionally, the Spanish law on science, technology and innovation (2011) includes the active participation of the citizen in its general objectives. However, as GómezFerri (2014) observed, there is no indication as to how this law will be implemented. Precipita is driven by the slogan "Activating collective science", and the citizen collaboration proposed is based on economic terms. The platform is called "Precipita" and, in the video explaining the philosophy of the platform, the metaphor of citizen contribution used is the chemical reaction of "precipitation" which, as recounted in the video, adds "the small and final element for everything to change".

a) Discipline: it only focuses on natural and physical sciences projects and does not include any human or social sciences projects. The search categories are: biomedicine, medicine, agriculture, computer science and computer technology, earth sciences, biology, mathematics, biology, physics, space sciences, and chemistry.

b) Task: the volunteers contribute through donations.

c) Volume of data: there are currently more projects geared to the dissemination of science in society. 
d) Design of research projects: the platform is clearly aimed at research teams since it is structured into two parts -one for searching for projects and the other for sharing projects. For a user to contribute to a project it is necessary to register with the site and two requirements must be fulfilled: the candidate must belong to a public research centre and must have contributed to scientific publications or dissemination in the last two years.

\section{Financing of European research projects through citizen participation}

The current European program for funding research and innovation, Horizon 2020 (H2020), aims to deepen the relationship between science and society. To achieve this, H2020 wants to promote the involvement of civil society in research and innovation by promoting science education, making scientific knowledge more accessible, and developing research and innovation agendas which deal with the concerns and expectations of society (Official EC for Horizon 2020, 2014).

The White paper on citizen science for Europe (Socientize Consortium, 2014), also promoted by the EU, highlights the flagship initiatives of Horizon 2020 related with citizen science participation. These initiatives are:

- Digital agenda for Europe: the link between society and science is based on reinvigorating the economy and, supporting citizens and businesses by making the most of ICT.

- Innovation union: it is worth highlighting that Europe has an opportunity for design, creativity, and social innovation.

- Youth on the move: emphasis is placed on the fact that learning does not just happen in the classroom.

- An industrial policy for the globalisation era: emphasis is placed on making a much needed change towards sustainability.

- An agenda for new skills and jobs: it is necessary for volunteers to develop new skills, especially in science, technology, engineering and mathematics, the so-called STEM fields. And

- European platform against poverty and social exclusion: citizen science participation is considered to be an element of social integration, since it encourages self-learning.

The proposals that receive the most funding from the European Union within the framework of the Horizon 2020 program for projects with citizen participation are called Citizens' observatories. These are projects in which the volunteers collect data, mostly in the field of the environment, to complement the observations of the official system and, officially and indirectly, to raise awareness among the local population and empower it.

In more specific fields, the EU has already financed 17 citizen science projects (Socientize Consortium, 2013). These projects figured in the $7^{\text {th }}$ Framework programme, which financed research and innovation from 2007 to 2013 . The shared feature of the projects was that they gathered together various case studies or sub-projects involving citizen science. The sub-projects generally focused on the discipline of the natural and physical sciences and the research design was carried out by a group of researchers. Volunteers provided data as if they were sensors distributed throughout the territory (for instance, to monitor animals, water, space, climate). They were allowed their personal computers to be connected remotely and used for the purpose at hand. Of the 17 projects, just 2 (Socientize and Engage) included initiatives outside the scope of natural science, technologies, or mathematics and focused on aspects of a more of human and artistic nature.

For example, Socientize was based in Saragossa Spain, but the experiment was conducted in Barcelona within the framework of the Sonar 2014 festival, with participants creating musical patterns from a set of audios or performing tasks such as image classification.

\section{Discussion}

In the last decade, we have witnessed a paradoxical phenomenon which suggests that the relationship between science and society is evolving. On the one hand, although we are part of a society that is technologically and economically advanced, where the development and application of scientific knowledge are essential and largely a socioeconomic imperative, its citizens are in average disinterested in themes of a 


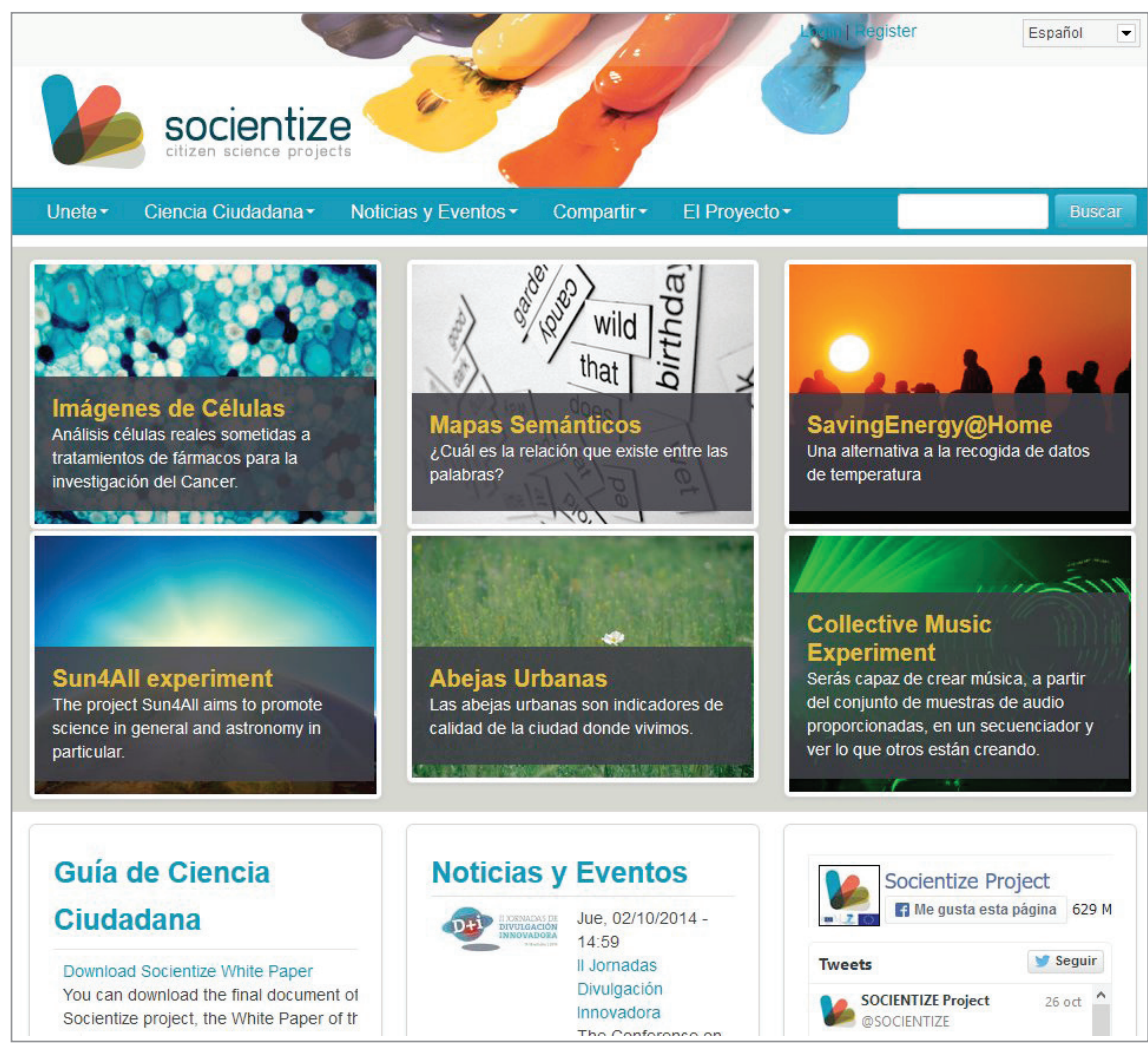

http://www.socientize.eu

scientific and technological nature. On the other hand there are new ways for people considered to be "non-experts" to participate actively in science (Gómez-Ferri, 2014), thanks to the democratization of knowledge and access to the Net.

As described in the review, citizen science projects in the arts, humanities, and social sciences (AHSS) are few. Although the proportion of investment in research and innovation in the sciences and engineering versus the social sciences and humanities is usually 70:30 (INE, 2003), the proportion for citizen science research projects is 99:1. For instance, in Wikipedia, out of a list of 81 projects, only one was about the social sciences or humanities (linguistics), and in SciStarter, of the 23 project classification categories, only 2 were on AHSS (archaeology and education).

The review also suggests that the forms of participation in citizen science projects vary. A basic classification of participation in projects can be divided into two levels: 1) nonscientists participate in the collection and analysis stages; and 2) non-scientists contribute to true decision making (Lewenstein, 2004). The BCNLab's Citizen Science Office agrees with this author that any scientific research carried out by non-professional scientists can be considered citizen science. However, in their Decalogue, they provide four levels of classification of citizen science volunteers:

1. "Crowdsourcing", citizens gather or process data;

2. "Distributed intelligence", citizens interpret data;

3. "Participatory science", citizens participate in the definition of problems, challenges, objectives, and in the collection of data; and

4. "Collaborative science", citizens design, together with scientists, the research to be carried out. This research must have a direct impact on the immediate environment of the citizens and be able to motivate very specific actions in the city (Citizen Science Office, 2015).

The most common forms of participation in citizen science projects in this study are at the basic level or, as other authors have defined, of the contributory type (Bonney et al., 2009), with volunteers providing data and observations for the project. In these cases, individual participation is not explicit; it is presented jointly and it is necessary to wait a while to see the results and publications (Wechsler, 2014). As seen in the research presented, these projects aim to capture massive quantities of data at a low cost, so that professional scientists can investigate and resolve research questions (Trumbull et al., 2000). The design of these studies is done by teams of researchers linked to centres of research or universities using a top-down approach. It is this type of project design that is better positioned to receive and indeed receives more financing from the EU.

Thus, while the projects are not usually on such an advanced level as those of the BCNLab, or what other authors have suggested are collaborative or co-creative ways of citizen science, the literature on citizen science emphasizes benefits for volunteers that go beyond the mere production of important databases. Volunteers increase their knowledge of the scientific process (Trumbull et al., 2000) and their skills and personal development (learning, fun) are enhanced. Moreover, the generation of large quantities of data is what makes science progress more rapidly (Franzoni; Sauermann, 2014). In the case of arts, humanities and social sciences, the effects have not yet been evaluated (Purdam, 2014).

Benefits for volunteers go beyond the mere production of databases: they increase their knowledge of the scientific process

Another line of research in the field of citizen science is the analysis of the quantity and quality of the research output produced by these initiatives (Franzoni; Sauermann, 2014). However, our case studies suggest that many of these initiatives in the area of social and human sciences are not aimed at producing research publications but rather at disseminating the role of science, training or supporting scientific initiatives in order to incorporate volunteers in the various phases of the scientific process and not just in the collection 
of data. In fact, we have not been able to present the results of the initiatives of these disciplines from the research done on the platforms for the dissemination of citizen science projects. A plausible hypothesis could be that these citizen science projects in the fields of social sciences and humanities are not worried about the quantity of data or quantity of volunteers that are involved.

What is clear is that citizen participation in science is a movement that shows that the traditional dividing line between the scientific and non-scientific is weak. However, the system of research, understood as entities such as funding bodies and elements of support to scientific processes, often sees citizens as mere contributors in the provision of data. In the context of the public research support system in Spain (Precipita platform), the volunteers do not appear to be taken into account in any phase of the scientific process, and the task they are invited to do is the financing of the research.

\section{Conclusions}

A content analysis of four virtual platforms for the dissemination of citizen science research projects shows that this sort of project in the area of arts, humanities and social sciences (AHSS) is almost non-existent. The ratio of science and engineering to social science and humanities is 99:1. Therefore, in these disciplines there is huge potential for growth in terms of citizen science initiatives. Areas such as audiovisual heritage or oral history are very likely to receive volunteer participation if cultural institutions promote this form of involvement.

For the present study, citizen science project platforms were used and, as AHSS projects could not be found, they could not be analyzed. Although proportionally there is a distinct imbalance with other disciplines, projects of this kind do exist. They are probably not published on these platforms because on many occasions they are not termed as citizen science projects and do not consider themselves as "carrying out science". However, in many cases, these projects can be considered as research projects partially carried out by non-professional scientists. Therefore, in the second

\section{In arts, humanities and social sciences (AHSS) citizen science research projects are almost non-existent}

stage of the research to be presented in this paper, we will analyze the interviews carried out with five AHSS initiatives at the beginning of this year:

- "Fem memòria", from the Biblioteca de Catalunya;

- "Transcriu-me", from the Filmoteca de Catalunya;

- "Prototips", from the Tàpies Foundation;

- "Public Participation GIS", from the Cartographic Institute of Catalonia; and

- "Testimonis bibliotecaris", from the Public Libraries Network of Catalonia.

This new line of research will try to distinguish if these citizen participation projects can be recognized as citizen

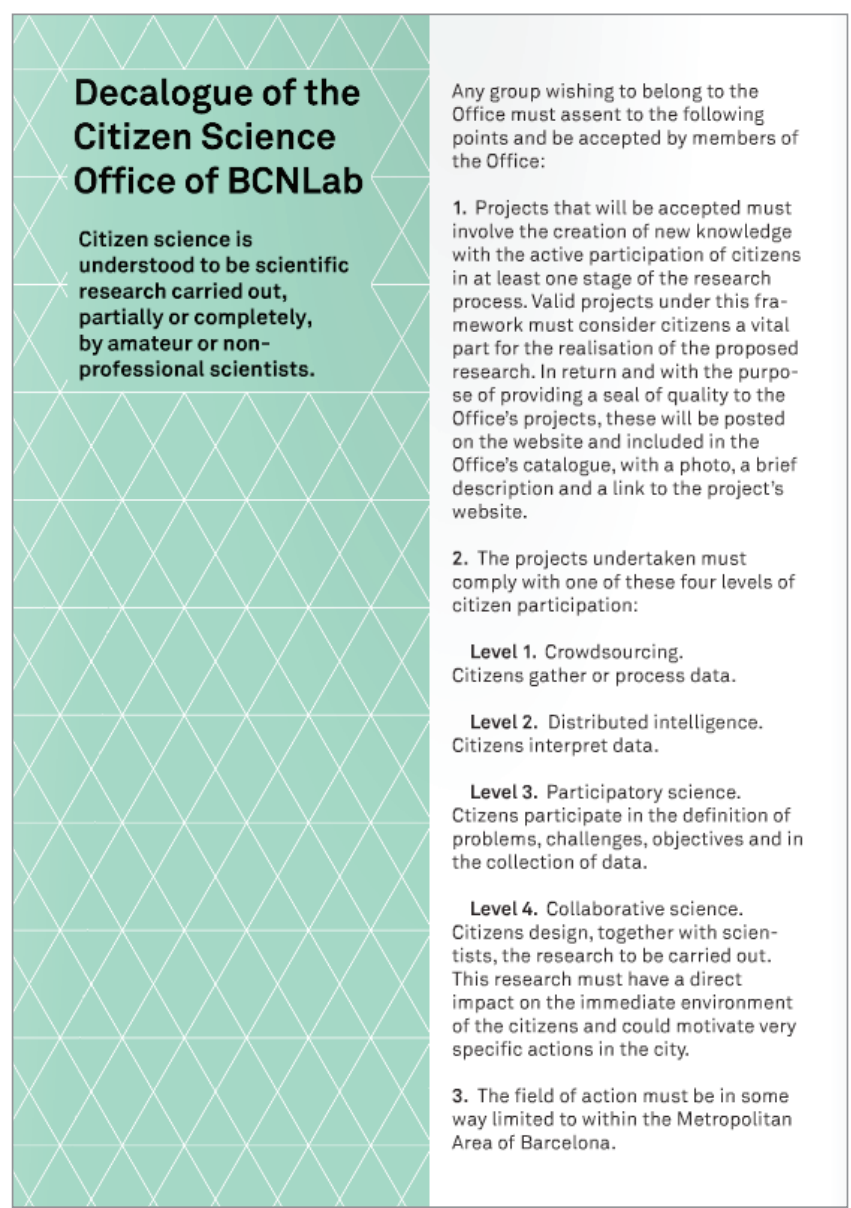

http://issuu.com/bcnlabcienciaciudadana/docs/llibret_icub_v.eng_

science projects, furthering the benefits organizations and volunteers receive from this kind of project and the benefits for society and the generation of new knowledge. Further research will focus on how to generate citizen science research projects in AHSS that can be categorized as levels two to four from the Decalogue of BCNLab's Citizen Science Office (2015). Citizens are active in these levels of participation in not only gathering and processing data, but also in the design stages of the research process.

This active participation has not been found in the content analysis of many of the natural and physical sciences projects, which are usually fostered with a top-down approach and in which volunteers participate in the data collection phase in order to obtain a large volume of data.

Until now, these projects, more related to Citizen's observatories, have received more financing from the European Union. In this sort of project, information management professionals are given a great opportunity to support the virtual platforms on which the data from volunteers are collected in order to ensure their validity. However, there is still an absence of citizen science projects of a more participatory nature, and virtual environments that promote communication in a structured manner could provide solutions to helping volunteers contribute to the interpretation of data or the discussion to define problems and challenges. In this case, the majority of projects could be considered collaborative. 
When citizen science research projects reach a participatory level where volunteers are truly involved in the research, only then will science come from citizens and not only from universities and research centers, with knowledge being created by the people, for the people.

\section{Notes}

1. Crowd science, citizen science, networked science or massively-collaborative science are terms used to speak about science with citizen involvement (Wiggins; Crowston 2011; citing Franzoni; Sauermann, 2014).

2. The term "crowdsourcing" was coined by Jeff Howe (2006), and ranges from micro-sponsorship actions (from Verkami, for instance) to collective wisdom.

3. Spain. Law 14/2007, of 1 June, on Science, Technology and Innovation. Boletín oficial del Estado, 2 June 2011, n. 131, pp. 54387-54455.

\section{Acknowledgements}

Part of the project "Open access to scientific production in Spain: analysis of the level of implementation and sustainability of a new model of scientific communication", National R\&D Plan (CSO2011-29503-C02-01/SOCI) and the Emerging Research Group Laika (2014 SGR 1271). Thanks for the comments received on the workshop organized by the Civic Epistemologies project on 10 July 2015 in Budapest (EU FP7 grant agreement no. 632694).

\section{Bibliography}

Antelio, Marcio; Esteves, Maria-Gilda P.; Schneider, Daniel; De Souza, Jano-Moreira (2012). “Qualitocracy: A data quality collaborative framework applied to citizen science". 2012 IEEE Intl conf on systems, man, and cybernetics (SMC), pp. 931-936. ISBN: 9781467317139

http://dx.doi.org/10.1109/ICSMC.2012.6377847

Bermuda (1996). Report of the International strategy meeting on human genome sequencing held at the Princess Hotel, Southampton, Bermuda, on 25th-28th February 1996 (unpublished manuscript, February 1996). Obtained via Freedom of Information Act (FOIA) request to the National Human Genome Research Institute (NHGRI), FOIA Case Number: 12-FOI-00224-NHGRI-39937

http://dukespace.lib.duke.edu/dspace/handle/10161/7715

Bonney, Rick; Shirk, Jennifer L.; Phillips, Tina B.; Wiggins, Andrea; Ballard, Heidi L.; Miller-Rushing, Abraham J.; Parrish, Julia K. (2014). "Next steps for citizen science". Science, v. 343, n. 6178, pp. 1436-1437.

http://dx.doi.org/10.1126/science.1251554

Busch, Akiko (2013). The incidental steward: Reflections on citizen science. New Haven: Yale Universty Press. ISBN: 9780300178791

http://dx.doi.org/10.1016/j.biocon.2013.10.016

Clark, Fiona; Illman, Deborah L. (2001). "Dimensions of civic science: Introductory essay". Science communication, v. 23, n. 1, pp. 5-27.

http://dx.doi.org/10.1177/1075547001023001002
Dawson, Diane (2012)."Open science and crowd science: Selected sites and resources". Issues in science and technology librarianship, Spring.

http://scholar.uwindsor.ca/Iripub/44

http://dx.doi.org/10.5062/F48913SM

Declaración de Berlín sobre acceso abierto: texto de la versión autorizada al español, aprobada el 22 de octubre de 2003 por representantes de varias instituciones europeas convocados por la Sociedad Max Planck http://openaccess.mpg.de/Berlin-Declaration

European Commission (2013). Guidelines on open access to scientific publications and research data in Horizon 2020. http://ec.europa.eu/research/participants/data/ref/h2020/ grants_manual/hi/oa_pilot/h2020-hi-oa-pilot-guide_en.pdf

Franzoni, Chiara; Sauermann, Henry (2014). "Crowd science: The organization of scientific research in open collaborative projects" (August 14, 2013). Research policy, v. 43, n. 1, pp. 1-20.

http://dx.doi.org/10.2139/ssrn.2167538

Gómez-Ferri, Javier (2014). "Ciència ciutadana o ciutadanies científiques? Quatre models de participació en ciència i tecnologia". International journal of deliberative mechanisms in science, v. 3, n. 1, pp. 24-48.

http://www.hipatiapress.info/hpjournals/index.php/ demesci/article/view/1197/998

http://dx.doi.org/10.4471/demesci.2014.13

Howe, Jeff (2006). "The rise of crowdsourcing". Wired, v. 14, n. 6, pp. 134-145.

Hunter, Jane; Alabri, Abdulmonem; Van-Ingen, Catharine. (2013). "Assessing the quality and trustworthiness of citizen science data", Concurrency and computation: Practice and experience, v. 25, n. 4, pp. 454-466.

http://dx.doi.org/10.1002/cpe.2923

Lewenstein, Bruce (2004). "What does citizen science accomplish?". Paper read at the CNRS Colloquium, June, Paris. http://hdl.handle.net/1813/37362

McLuhan, Marshall (1964). Understanding media: The extensions of man. New York: McGraw-Hill.

Museu de Ciències Naturals; Institució Catalana d'Història Natural (2010). Conclusions de la Jornada "El valor dels projectes de voluntariat en el coneixement i la gestió de la biodiversitat", Museu de Ciències Naturals, Barcelona, 13 de maig de 2010.

http://ichn.iec.cat/pdf/VolBiodiv_conclusions.pdf

Nielsen, Michael (2011). Reinventing discovery: the new era of networked science. Princeton, NJ: Princeton University Press. ISBN: 9781400839452 http://dx.doi.org/10.1515/9781400839452

Oficina de Ciència Ciutadana (2015). Ciència Ciutadana. 20 projectes per fer ciutat. Barcelona: Ajuntament de Barcelona. Institut de Cultura. B.12402-2015.

http://issuu.com/bcnlabcienciaciudadana/docs/llibret_ icub_v.cat_

Perelló, Josep (2014). "Citizen science: Knowledge takes power". En: CCCB LAB. Research and innovation in the cul- 
tural sphere CCCB. 24-04-2014.

http://blogs.cccb.org/lab/en/article_ciencia-ciutadanaconeixement-al-poder

Purdam, Kingsley (2014). “Citizen social science and citizen data? Methodological and ethical challenges for social research". Current sociology, v. 62, n. 3, pp. 374-392.

http://dx.doi.org/10.1177/0011392114527997

Socientize Consortium (2013). Green paper on citizen science. http://ec.europa.eu/newsroom/dae/document.cfm?doc_ $i d=4121$

Socientize Consortium (2014). White paper on citizen science for Europe.

http://socientize.eu/?q=eu/content/download-socientizewhite-paper

Subirós, Olga; De-Vicente, José-Luís (com.) (2014). Big bang data. Exposición celebrada en Barcelona, CCCB, 9 de mayo - 16 de noviembre.

http://www.cccb.org/es/exposiciones/ficha/big-bangdata/45167

Tomales Bay Institute (2006). The commons rising.
http://bollier.org/sites/default/files/Commons Rising_06.pdf

Trumbull, Deborah J.; Bonney, Rick; Bascom, Derek; Cabral, Anna (2000). "Thinking scientifically during participation in a citizen-science project". Science education, v. 84, n. 2, pp. 265-275.

Wechsler, Dietmar (2014). “Crowdsourcing as a method of transdisciplinary research - Tapping the full potential of participants". Futures, v. 60, pp. 14-22.

http://dx.doi.org/10.1016/j.futures.2014.02.005

Wiggins, Andrea; Crowston, Kevin (2012). "Goals and tasks: Two typologies of citizen science projects". Fortyfifth Hawai's int conf on system science (HICSS-45). ISBN: 9781457719257

http://crowston.syr.edu/sites/crowston.syr.edu/files/hicss45-final.pdf

http://dx.doi.org/10.1109/HICSS.2012.295

Zhao, Yuxiang; Zhu, Qinghua (2014). "Evaluation on crowdsourcing research: Current status and future direction". Inf syst front, v. 16, n. 3, pp. 417-434.

http://dx.doi.org/10.1007/s10796-012-9350-4

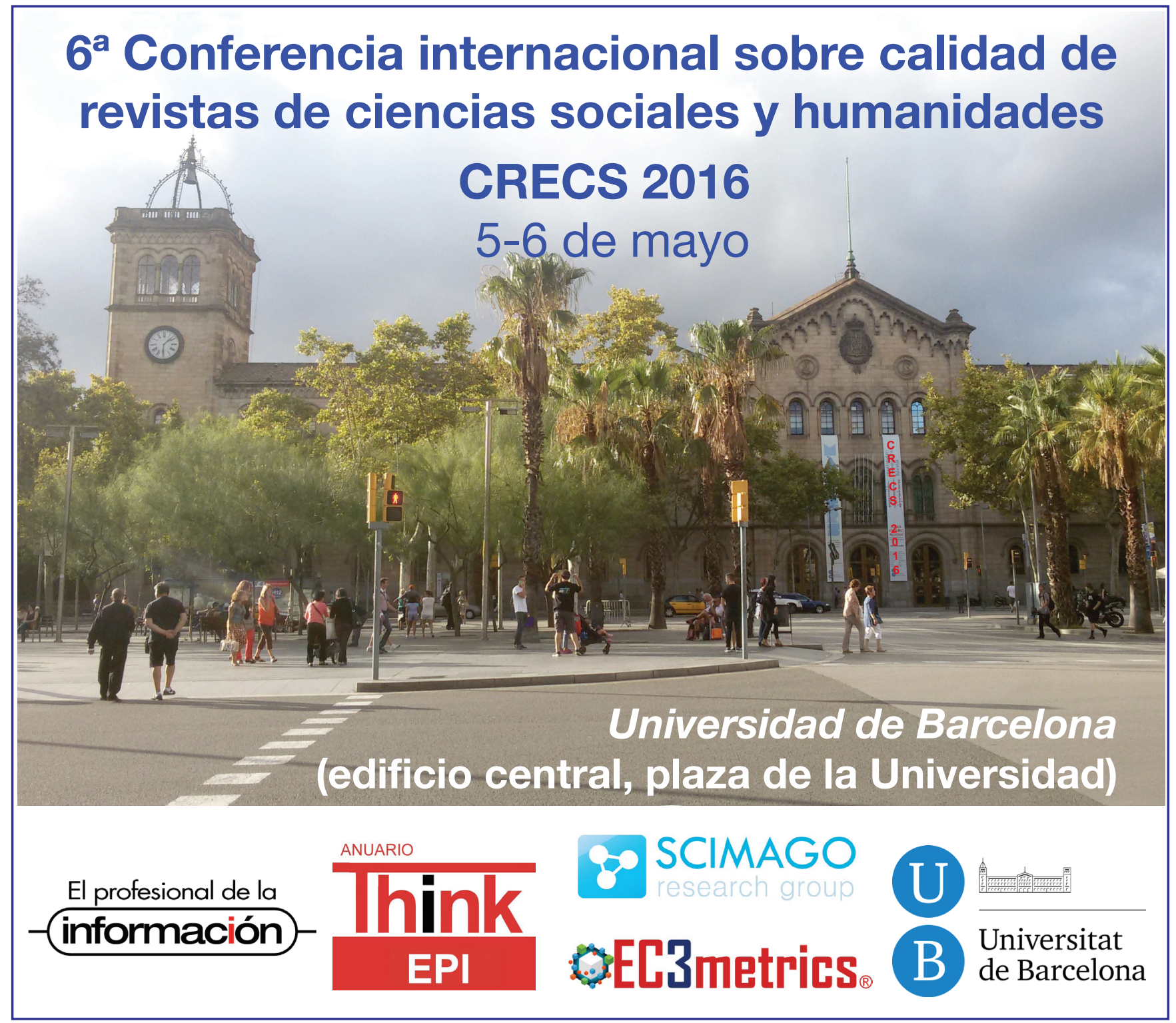

